\title{
Informality and Economic Growth in Nigeria: 1980-2014
}

\author{
Mohammed Yelwa $^{1 *} \&$ A. J. Adam ${ }^{1}$ \\ ${ }^{1}$ Department of Economics, University Of Abuja, Abuja, Nigeria \\ *Mohammed Yelwa, E-mail: yelwamhmmd@gmail.com
}

Received: December 14, 2016

Accepted: December 24, 2016

Online Published: July 31, 2017

doi:10.22158/jepf.v3n3p405

URL: http://dx.doi.org/10.22158/jepf.v3n3p405

\begin{abstract}
The paper examines the impact of informal sector activities on economic growth in Nigeria between 1980-2014. The contributions of informal sector activities to the growth of Nigerian economy cannot be over emphasized. It is the source of livelihood to the majority of poor, unskilled, socially marginalized and female population and is the vital means of survival for the people in the country lacking proper safety nets and unemployment insurance especially those lacking skills from formal sector jobs. The relationship between informality and economic growth is not clear because the sector is not regulated by the law also there is no concrete evidence that this sector enhances growth because the sector's contributions to growth is not measured. The use of endogenous growth model becomes relevant in this study. The theory emphasizes the role of production on the long-run via a higher rate of technological innovation. The variables that were tested are official economy nominal GDP, informal economy nominal GDP, currency in circulation, demand deposit, ratio of currency in circulation to demand deposit, narrow money, informal economy as percentage of official economy. ADF test was conducted to establish that the data series of all variables are stationary $t$ levels. Having established the stationarity test we also, conducted causality test of the response of official economy nominal GDP to informal economy nominal GDP. In conclusion, the impact of informal sector economy on economic growth in Nigeria is quiet commendable. Even though, the relationship between informality and economic growth is not straight. The paper recommended thus, the need for the government to integrate the activities of the informal economy into formal sector and size of the sector is measured and regulated because their roles are commendable. As it will improve tax collection and enhance fiscal policy.
\end{abstract}

Keywords

informality, economic growth, GDP and livelihood

\section{Introduction}

The benefit of the informal sector activities in supporting livelihoods and contributing to consumption and production in developing countries in areas of job creation and employment generation is quite 
commendable and widely evident. However, there is no agreeable definition of informality across the globe which has hampered its recognition and measurement for proper comparism. In addition, its relationship with economic growth is not straight forward because the sector is not regulated or recognize by the law, also there is no concrete evidence that this sector enhances economic growth, because the sector's contribution to growth is not measured (Yelwa, 2012).

It is a source of livelihood to a majority of the poor, unskilled, socially marginalized and female population and is a vital means of survival for people in countries lacking proper social safety nets and unemployment insurance especially those lacking skills from formal sector jobs. Apart from being a major source of employment particularly people at the rural areas, the informal economy also contributes significantly to the output of developing countries. According to the World Bank estimates, the informal economy accounts for 40 percent Gross National Product (GNP) of low-income countries. The informal sector is a broad term that refers to that part of an economy that is not taxed, monitored by any form of government, or included in any Gross National Product (GNP). It is sometimes referred to as the underground market, black market, illegal market or even the shadow economy (Becker, 2004). Even though, the sector is not regulated by any existing government law but to a large extent the sector provides employment opportunities to rural dwellers, therefore not all activities are illegal or forbidden. Although, it is difficult to measure the size of the informal economy because of its vagaries activities, various efforts are made to measure its size but there is no consistent measure to make international comparison (Becky, 2004). So far, estimate shows that the non-agricultural employment share of the informal work force is 78 percent in Africa, 57 percent in Latin America and the Caribbean, and 45-85 percent in Asia (Ilo, 2013).

In developing countries, self-employment comprises a greater share of informal employment than wage employment. Specifically, self-employment represents 70 percent of informal employment in sub-Saharan Africa, 62 percent in North Africa, 60 percent in Latin America and 59 percent in Asia.

Consequently, informal wage employment in the developing world constitutes 30 to 40 percent of the informal employment outside of agriculture (Becky, 2004). In a related development Awoyemi (2012); Ekpo and Umoh (undated) on their part opine that activities of the informal sector can be categorized into three board categories. These are:

(i) The informal productive sub-sector: This encompasses all economic activities including the production of tangible goods. These include agriculture production, mining and quarrying (Excluding Petroleum), small-scale manufacturing, building and construction. Specifically, they manifest in food production. Woodwork, furniture making, garment making, welding and iron work etc.

(ii) Informal service sub-sector: This sub-sector includes repairs and maintenance, informal education services, health services, counseling services as well as labour or menial work. Repairs and maintenance services include tailoring, vehicle repairs and maintenance, tinkering, carpentry and servicing of various household and commercial tools. Informal health services, especially in the rural areas, include traditional birth attendants, herbalists and other traditional medical practitioners. There 
are also traditional spiritualists who offer counseling services. These services are rendered for fees paid to those who render them.

(iii) Informal financial sub-sector: The activities of this sub-sector are mostly unofficial, irregular, informal, shadowy and parallel. The most predominant type of informal finance in Nigeria is the ESUSU. Among the Yoruba, it is called either ESUSU, Ajo. Among the Igbo, it is called Isusu or Utus. Some groups operate with written laws while others operate with unwritten laws but on oath of allegiance and mutual trust.

\section{Literature Review}

\subsection{Monetary Policy and Informal Financial Market in Nigeria}

Monetary policy is one of the viable tools of macroeconomic management. It aims at controlling the growth of monetary aggregates and assists either policy tools to achieve macroeconomic goals and low inflation, balance of payments viability and sustainable output growth could be attained. It is generally believed that monetary policy works in concert with other policy tools to enhance the achievement of overall macroeconomic objectives. Therefore, monetary policy is central to macroeconomic management and is indeed supportive of other policy tools, especially fiscal policy. The integration between financial markets, economic growth and monetary policy is a crucial issue for Central Bank. The continued integration and keeping of financial markets is a significant issue for policy-makers, and particularly for Central Bank, since the functioning and efficiency of the financial markets are crucial in ensuring smooth transmission of monetary impulses to the economy. It is also known that monetary policy helps to promote orderly development of the financial markets as well as share the behaviour of the market participants (Masha, 2004).

The monetary authorities use monetary targeting to achieve the objectives of monetary policy. Monetary targets include intermediate variables such as the rate of growth of money supply, supply in the volume of aggregate credit, the level and structure of interest rates and exchange rates.

The aims of targeting the growth of money supply are that it is closely linked with inflation and balance of payments position. The volume of aggregate credit is determinant of money supply. The level and structure of interest rates affect the basic conditions of the Money Market. While the exchange rate links the domestic economy with the external sector. Monetary indicators, on the other hand, are those variables that signal to the monetary authorities the monetary conditions of the economy and therefore the direction and effectiveness of monetary policy. They include movement in monetary base, base reserves and short-run interest rates. Monetary base will influence changes in money supply, aggregate credit and long-run interest rates. The level of bank reserves balances has similar effect while short-run interest rates will influence long run interest rates, aggregate credit and money supply. Monetary policy influences the availability and cost of money in the economy. In ensuring monetary stability, the Central Bank through the deposit money banks implements policies that guarantee the orderly growth and development of the economy through appropriate change in the level of money supply. Monetary 
policy influences the availability and cost of money in the economy. In ensuring monetary stability, the Central Bank through the deposit money banks implements policies that guarantee the orderly growth and development of the economy through appropriate change in the level of money supply. The reserves of the banks are influenced by the Central Bank through its various instruments of monetary policy. These instruments include the cash reserve requirements, liquidity ratio, open market operations and primary auction of treasury bills. Also the central bank uses the discount window operations to influence the movement of bank reserves. All these activities affect the banks in their credit operations and thus influence the cost and availability of loanable funds. Thus, the financial markets provide a useful channel for the implementation of monetary policy. An efficient and well-organized market will therefore enhance the speed of monetary policy transmission.

However, the existence of a large informal financial market in an economy is detrimental to effective financial intermediation as well as hampers the effectiveness of monetary policy actions. When a large amount of money is outside the banking system, the ability of the central bank to influence financial and monetary conditions through the manipulation of deposit money bank's reserve balance using indirect monetary policy instruments is impaired. In this regard, Nnanna (2001) identifies the existence of dualistic financial markets as a serious constraint to monetary policy management in Nigeria. The best contribution that monetary policy can make to the smooth functioning of the financial markets and the economic growth is to maintain a steady medium-term price stability. Such a policy outcome will be beneficial as it will minimize the adverse effects of inflation price stability will not operate a climate for higher economic over the medium term, but also reduce the economic and social inequalities caused by the asymmetric distribution of the costs of inflation among the various economic agents.

\subsection{Stylized Facts on Informality and Economic Growth}

The nexus between economic growth and informality is always a thing of interest at different point in time. Before now Economic growth was noted to be growth of organized economic activities via speedy industrialization which aid capital formation and increase domestic output and enhance export of goods and services. Also, with this increase in per capita income, wealth creation and human capital development, economic activities were assumed to be organized. But has is actual on ground does not match with the vision of economic transition in the world. The market failed to recognize or take into account the ever growing number of people who were found largely in the activities outside the formal sector. Originally, informal sector was viewed as a temporary situation that would vanish with the take-off in economic growth.

The expansion of the informal economic over several years and the reduction in employment situation in many developing countries has believed to be associated with low GDP growth rates (ILO, 2004). As noted from many recent works or research, this view about informality and economic growth may not be entirely valid. For example, Latin America experienced economic recovery and growth in the 1990s but it is still faced with an increase in unemployment (Becker, 2004). Until the recent crises $n$ the global economy, SSA experienced one of the fastest growth rates in the history and also in the world 
over the last six years, and get this did not affect negatively the size of the informal economy. There is indeed evidence of an ever expanding informal economic in this region. In 2014, Nigeria economic was debase indicating that all sectors of the economy has grown over the period and yet did not affect negatively the size of the informal economy, in fact the informal economy in Nigeria is main source of livelihood of people living in rural areas. In Ghana, real GDP growth has average 5.2\% in the past two decades, rising to more than 6 percent since 2006 and yet the informal economy shape of total employment has increased from $80.5 \%$ between $1987 / 1988$ to $88.6 \%$ between $2005-2006$. It is important to clear that since the late 1960s and 1970s, very significant of population in developing nations have suffered negligence of lack of gainful employment and are organized in informal activities. Economic growth seems to be unable to reduce the sizes of the informal economy first among us.

This may be as result of increased population growth and urban migration. Hence, active labour force grows at a much faster rate than the availability of jobs in the organized or formal sector. Nigeria as a nation experience "youth bulges" a situation when young people or active people comprises at least 10 percent of the population. This is a serious concern to the policy makers and government as this may lead to frustration and social unrest if the preparations of the population (young men) are not gainful employed over time. The contribution of globalization to high unemployment rates in developing economies is quite evident. The disintegration of production and the integration of trade, whereby global buyers are out sourcing some of their activities in labour advantageous regions have led to the retrenchment of many low-skilled workers who had originally been involved in the activities being out sourced (Feenstra, 1998). Noting this analysis, there have been suggestions that in some countries the informal economy is proffered, and is entered voluntarily (Chen, 2004). The reason often given is that there are complementarities that exist between the formal and informal economies which make it impossible to completely transform the informal economy to a formal one. Chen (2004) argues that most informal enterprises and workers are indirectly linked to formal firms. There is believed that the nexus between economic growth and informality is driven to a large extent by how growth impacts the lives of the poor in an economy and what access the poor may have to the growth points in an economy. Using the monetary approach (Guttman, 1977) have shown that income generated in the informal sector is a significant proportion of official GDP, especially in African countries. Two studies on Tanzania used the monetary approach to estimate the informal economy. Bagachwa (1994) estimated it at $31.4 \%$ of the official GDP in 1986, while Osoro(1995) estimated it at $28.35 \%$ in the same year.

In a study by Magbagbeola (2000) in which he estimated the growth of the informal financial sector (proxy by total deposit to money supply, M2). Evidence show that between 1990 and 1996, the informal financial sector in Nigeria recorded a growth rate of 34\%, the formal financial sector suffered a decline of 10.29 percent. In Uganda income generated in the informal sector was estimated at two third in 1980 , Ghana it was $32.4 \%$ in 1982 , in Nigeria at $20 \%$ in 1989. In developed countries like Australia, income generated in the informal sector was estimated at 10\% of official GNP in 1978-1979; in Canada at $14 \%$, USA at $14.3 \%$, in the U.K at $7.5 \%$ in 1979. In Nigeria, the ratio stood at $49.7 \%$ in 
$1970,32 \%$ in $1975,8.6 \%$ in 1981 moved to $46 \%$ in 1985 dropped to $14.8 \%$ in 1990 , it was $3.4 \%$ and 5.3\% in 1995 and $7.8 \%$ in 2005 and 2010 respectively, and settled to 4.2 in 2012 (ILO, 2012).

\subsection{Is There Relationship between informality and Economic growth?}

The issues regarding Economic growth and informality are not clear but are wide and varied. However, whether informality leads to economic growth or not is an issue that has been discussed and analyzed by many agents of government, policy-makers and or economist. There are those who advocate growth at all cost and those who suggest that the emphasis be placed on policies that directly affect informal sector activities. Yet, the impact of informality on economic growth depends on the nature, strength and other characteristics of the links that exist between informality and growth at a given point in time and in particular country. The issue of economic growth is a difficult concept to direct countries to follow a strategy of growth maximization.

Technically, different growth strategies induce different patterns of growth that differ in both the rate of economic growth and the resulting Distributing of income (Aryeetey \& Hettige, 1997). The relationship between informality and economic growth can determine either growth strategy is pro-poor or broad-based growths. It is important to clear that pro-poor growth is targeted at all such of expenditure that directly serve the objective of poverty alleviation particularly at informal economy, and broad-based growth focuses on government expenditure by way of enhancing GDP in the first instance and the results of increased GDP can lead to thriftiness and hence poverty reduction. For the purpose of emphasis, the nexus between growth and informality cannot easily be measured because informal activities worldwide are not regulated by the government, particularly those that operate in the rural areas, they lacked social safety nets and managerial skills therefore, keeping records of sorts of transactions becomes difficult.

\subsection{Rationale for Informal Sector Economy}

The importance of informal economy to domestic production cannot be emphasized. The sector was noted as a means of livelihood in developing countries particularly the rural dwellers. They have the prowess to create job opportunities and alleviating poverty. Evidence has showed that large number of consumer demand in the economy is catered by the informal economy; the problem is what are the quantities of goods and services they are to produce? The degree of production in stimulating consumption? This problem arises because the sector is not regulated. The medium of communication or interaction amongst other economic agents in a typical African economy is outmoded.

\subsection{Informal Sector Activities and Inclusive Growth}

The concept of inclusive growth demands analysis of how employment opportunities arise and change with growth process. Economic growth can enhance by the increase in the activities of informal economy or employment. For example, in Nigeria the role of informal economy activities is quite commendable even though, there are bottlenecks in terms of size and measurement, but informal wage employment or sub-contracted self-employment has shown clear supportive evidence to economic growth by reducing the cost of labour and improving competitiveness; since large number of this 
category are unskilled they also serve as a raw materials in a formal industrial sector, but keeping unskilled workers in a "formal" industrial sector for a long-term period will lead to low levels of productivity and dismal earnings and this will put the growth in to a standstill. In order to enhance productivity there is need to integrate labour out of low-quality employment into more productive activities. This could also mean there is a reduction in the proportion of people informally employed would constitute an important element of an employment focused approach to inductive growth (Aryeeteey, 2015).

This paper proposes operational definition of the informal sector activities and also provides a relationship between informality and economic growth in Nigeria using some macroeconomic variables.

\section{Methodology and Theoretical Framework}

This section presents the analytical procedure adopted in this study which includes source of data, model specification, method of analysis and a priori expectation on the study "informality and the economic growth in Nigeria. The use of endogenous and Lucas growth models becomes relevant.

\subsection{Model Specification}

We proceed to specify the baseline empirical model which captures the hypothesized relationship among the core variables under investigation. The endogenous growth theory is considered. The theory of course emphasizes the role of production on the long-run growth via a higher rate of technological innovation Lucas (1988); Romer (1986). Thus we adapt Lucas (1986). The model is specified thus:

$$
\text { OFECON }_{t}=\mathrm{f}\left(\text { IFECON }_{\mathrm{t}}, \text { IFEGDP }_{\mathrm{t}}, \mathrm{CIC}_{\mathrm{t}}, \mathrm{DD}_{\mathrm{t}}, \mathrm{CDD}_{\mathrm{t}}, \mathrm{M} 1_{\mathrm{t}}, \mu_{\mathrm{t}}\right)
$$

The functional equation (1) is represented in an explicit form as equation (2) below:

$$
\text { OFECON }_{t}=\beta_{0}+\beta_{1} \text { IFECON }_{t}+\beta_{2} \text { IFEGDP }_{t}+\beta_{3} \text { CIC }_{t}+\beta_{4} \text { DD }_{t}+\beta_{5} \text { CDD }_{t}+\beta_{6} \mathrm{M}_{t}+\mu_{t}
$$

Where:

Official Economy Nominal GDP (OFECON), Informal Economy Nominal GDP (IFECON), Currency in Circulation (C), Demand Deposit (DD), Ratio Of Currency in Circulation to Demand Deposit (C/DD), Narrow Money (Currency in Circulation plus Demand Deposit) M1, Informal Economy as Percentage of Official Economy GDP (\%) (IFEGDP).

$\mu_{t}$ : the Stochastic or Error Term which stands for the influence of other exogenous variables not captured in the model.

$\beta_{0}$ : Constant or intercept parameter, $\beta_{1}, \beta_{2}, \beta 3, \beta_{4}$ and $\beta_{5}$ : Parameters or Partial Slopes for the Multiple Regression Model.

In lieu of the nature of this study and the data which suit the essence of this study, a secondary data is employed, sourced from the Central Bank of Nigeria (CBN) Annual Statistical Bulletin, National Bureau of Statistics (NBS) Annual Publication. Our empirical analysis will involve 3 steps: Unit root test for the variables, Ordinary Least Square estimation technique (OLS) and Granger causality test. 


\section{Empirical Analysis and Policy Implications of the Result}

The analysis is based on time series data. This therefore requires some specific approaches to the analysis. It is generally known that the econometric estimation of a model based on time series data demands that the series be stationary, as non-stationarity series usually results in misleading inferences. Engle and Granger (1987) provided a standard technique to deal with this problem. This involves testing the variables of an equation for stationarity by running the regressions for all the series at both first difference and at levels, with constant and trend in the equation employing the Augmented Dickey Fuller (1979) ADF test. The ADF tests are presented in Table 1 appendix. The ADF unit root test result presented in Table 1 appendix establishes that the data series of all variables are stationary at levels, i.e., the absolute values of the ADF test statistics of the variables are greater than the absolute values of the $5 \%$ critical value of the ADF statistics.

Table 1. ADF Test Result

\begin{tabular}{llll}
\hline Variable & t-STATISTIC AT Levels & CRITICAL VALUE at 5\% & Order of integration \\
\hline OFECON & 4.399907 & -2.957110 & $\mathrm{I}(0)$ \\
IFECON & 15.23969 & -2.967767 & $\mathrm{I}(0)$ \\
IFEGDP & -5.765473 & -2.960411 & $\mathrm{I}(0)$ \\
CIC & 3.670579 & -2.991878 & $\mathrm{I}(0)$ \\
DD & 4.459367 & -2.971853 & $\mathrm{I}(0)$ \\
CDD & -5.319508 & -2.957110 & $\mathrm{I}(0)$ \\
M1 & -3.687576 & -2.957110 & $\mathrm{I}(0)$ \\
\hline
\end{tabular}

Source: Authors computation, 2015.

Having established the stationarity level of the variables, we proceed to establish causality test.

Table 2 appendixes presented the Pairwise Granger Causality Test; the first line results display the Granger Causality test of the response of Official Economy Nominal GDP to Informal Economy Nominal GDP. The result of the Table 2: indicates F-ratio of 19.91 and 29.79. This shows a bilateral relationship between Official Economy Nominal GDP and Informal Economy Nominal GDP. At line 3, with F-ratio 5.32 and 14.14, it implies Currency in Circulation significantly Granger Cause Official Economy Nominal GDP and Official Economy Nominal GDP significantly Granger Cause Currency in Circulation. At line 4, with F-ratio 2.9 implies that Demand Deposit does not Granger Cause Official Economy Nominal GDP. Thus, a unilateral directional causality exists between Demand Deposit and Official Economy Nominal GDP. Focusing on the direction of causality between ratio of Currency in Circulation to Demand Deposit, the $5^{\text {th }}$ line reports this result, at 5\% significant level, F-ratios of 4.45 and 13. 15 passed the significant test that a bilateral causal relationship exists between ratio of Currency in Circulation to Demand Deposit and Official Economy Nominal GDP, thus rejecting the 
null hypotheses. At line 6, the F-ratio 5.31 and 4.06, give us enough evidence to reject the null hypotheses of a bilateral causal relationship between Money Supply and Official Economy Nominal GDP at 5\% significant level. Line 8 presents the result of the causal relationship between Currency in Circulation and Informal Economy Nominal GDP. The F-ratio 28.84 and 24.99 provides enough evidence to reject the null hypotheses of a bilateral causal relationship between Currency in Circulation and Informal Economy Nominal GDP. Implying that Currency in Circulation significantly granger causes Informal Economy Nominal GDP and Informal Economy Nominal GDP significantly Granger cause Currency in Circulation. Line 9 result similarly follows the same analysis. With the F-ratio 475.04 and 119.72, the null hypotheses are rejected at 5\% significant level that a bi-lateral relationship exists between Demand Deposit and Informal Economy Nominal GDP. The result from line 17 shows that a directional causality exist between ratio of Currency in Circulation to Demand Deposit and Currency in Circulation with F-ratio of 18.48 at $5 \%$ significant level. This implies that Currency in Circulation significantly Granger causes ratio of Currency in Circulation to Demand Deposit. Focusing on the Granger causality result from line 18 at 5\% significant level with an F-ratio of 3.74, the null hypothesis is rejected. Thus, Money Supply is Granger Causing Currency in Circulation. At line 19, the result shows that, at 5\% significant level with a F-ratio of 53.19, the null hypothesis is rejected. Thus, we conclude that Money Supply Granger causes Currency in Circulation. At the $21^{\text {st }}$ line, at $5 \%$ significant level the result shows that with a F-ratio of 2.75 , we reject the null hypothesis, thus concluding that ratio of Currency in Circulation to Demand Deposit Granger causes Money Supply.

Table 2. Pair Wise Granger Causality Test Result

Pairwise Granger Causality Tests

Date: 08/06/15 Time: 05:12

Sample: 19812013

Lags: 2

Null Hypothesis:

IFECON does not Granger Cause OFECON

Obs F-Statistic Prob.

OFECON does not Granger Cause IFECON

$30 \quad 19.9060 \quad$ 7.E-06

IFEGDP does not Granger Cause OFECON

29.7870

2.E-07

OFECON does not Granger Cause IFEGDP

$\begin{array}{lll}30 & 1.77235 & 0.1906\end{array}$

CIC does not Granger Cause OFECON

0.02308

0.9772

OFECON does not Granger Cause CIC

$\begin{array}{lll}31 & 5.32410 & 0.0115\end{array}$

DD does not Granger Cause OFECON

14.1473

7.E-05

OFECON does not Granger Cause DD

2.93336

0.0710

CDD does not Granger Cause OFECON

1.85717

0.1762

OFECON does not Granger Cause CDD

$\begin{array}{lll}31 & 4.98226 & 0.0147\end{array}$

$13.1512 \quad 0.0001$ 
M1 does not Granger Cause OFECON

OFECON does not Granger Cause M1

IFEGDP does not Granger Cause IFECON

IFECON does not Granger Cause IFEGDP

CIC does not Granger Cause IFECON

IFECON does not Granger Cause CIC

DD does not Granger Cause IFECON

IFECON does not Granger Cause DD

CDD does not Granger Cause IFECON

IFECON does not Granger Cause CDD

M1 does not Granger Cause IFECON

IFECON does not Granger Cause M1

CIC does not Granger Cause IFEGDP

IFEGDP does not Granger Cause CIC

DD does not Granger Cause IFEGDP

IFEGDP does not Granger Cause DD

CDD does not Granger Cause IFEGDP

IFEGDP does not Granger Cause CDD

M1 does not Granger Cause IFEGDP

IFEGDP does not Granger Cause M1

DD does not Granger Cause CIC

CIC does not Granger Cause DD

CDD does not Granger Cause CIC

CIC does not Granger Cause CDD

M1 does not Granger Cause CIC

CIC does not Granger Cause M1

CDD does not Granger Cause DD

DD does not Granger Cause CDD

M1 does not Granger Cause DD

DD does not Granger Cause M1

M1 does not Granger Cause CDD

CDD does not Granger Cause M1

\begin{tabular}{|c|c|c|}
\hline \multirow[t]{2}{*}{31} & 5.30910 & 0.0117 \\
\hline & 4.05920 & 0.0292 \\
\hline \multirow[t]{2}{*}{30} & 0.09616 & 0.9087 \\
\hline & 0.10712 & 0.8988 \\
\hline \multirow[t]{2}{*}{30} & 28.8454 & 3.E-07 \\
\hline & 24.9961 & 1.E-06 \\
\hline \multirow[t]{2}{*}{30} & 475.044 & 1.E-20 \\
\hline & 119.722 & 2.E-13 \\
\hline \multirow[t]{2}{*}{30} & 1.67482 & 0.2077 \\
\hline & 0.42756 & 0.6568 \\
\hline \multirow[t]{2}{*}{30} & 1.54005 & 0.2340 \\
\hline & 1.88364 & 0.1730 \\
\hline \multirow[t]{2}{*}{30} & 0.23243 & 0.7943 \\
\hline & 0.67103 & 0.5201 \\
\hline \multirow[t]{2}{*}{30} & 0.17089 & 0.8439 \\
\hline & 0.26975 & 0.7658 \\
\hline \multirow[t]{2}{*}{30} & 0.36559 & 0.6974 \\
\hline & 0.38444 & 0.6848 \\
\hline \multirow[t]{2}{*}{30} & 0.00638 & 0.9936 \\
\hline & 0.47042 & 0.6302 \\
\hline \multirow[t]{2}{*}{31} & 12.2563 & 0.0002 \\
\hline & 0.04509 & 0.9560 \\
\hline \multirow[t]{2}{*}{31} & 0.20601 & 0.8151 \\
\hline & 18.4751 & 1.E-05 \\
\hline \multirow[t]{2}{*}{31} & 3.74372 & 0.0373 \\
\hline & 1.87118 & 0.1741 \\
\hline \multirow[t]{2}{*}{31} & 53.1883 & 6.E-10 \\
\hline & 0.10730 & 0.8987 \\
\hline \multirow[t]{2}{*}{31} & 0.24496 & 0.7845 \\
\hline & 2.14111 & 0.1378 \\
\hline \multirow[t]{2}{*}{31} & 0.20848 & 0.8132 \\
\hline & 2.74585 & 0.0828 \\
\hline
\end{tabular}

Source: Author's Computation, 2015.

The OLS estimates presented in Table 3 appendix establishes that, Informal Economy Nominal GDP has a positive relationship with Official Economy Nominal GDP. A unit change in Informal nominal GDP will on the average bring about 0.87 unit change in Official Economy Nominal GDP, while Published by SCHOLINK INC. 
holding other explanatory variables constant. The parameter estimate of Informal economy nominal GDP was found to be statistically insignificant as its absolute t-statistic value is less than the absolute value of the 5\% critical value of t-statistic. This implies that the hypothesis of Informal Economy Nominal GDP having no impact on Official Economy GDP at 5\% level of significance is accepted. While Informal economy as Percentage of Official economy GDP is found to have a negative relationship with Official Economy Nominal GDP. A unit increase in Informal Economy as Percentage of Official Economy GDP will on the average bring about 173 unit decrease in Official Economy Nominal GDP, while holding other explanatory variables constant. The parameter estimate of Informal Economy as Percentage of Official Economy GDP is statistical insignificant to changes in official nominal GDP, as its absolute t-statistic value is less than the absolute value of the $5 \%$ critical value of t-statistic. On the contrary currency in circulation has a positive relationship. A unit change in currency in circulation will on the average result in 14.99 unit change in Official Economy Nominal GDP, while holding other explanatory variables constant. The parameter estimate of Currency in Circulation was found to be statistically significant to changes in official nominal GDP, as its absolute t-statistic value is less than the absolute value of the 5\% critical value of t-statistic. Also, Demand Deposit shows a positive relationship with Official Economy Nominal GDP. A unit change in Demand Deposit will on the average bring about 0.002 unit change in Official Economy Nominal GDP, while holding other variables constant. The parameter estimate of Demand Deposit was found to be statistically insignificant to changes in Official Economy Nominal GDP, as its absolute t-statistic value is less than the absolute value of the $5 \%$ critical value of $t$-statistic.

Ratio of Currency in Circulation to Demand Deposit has a negative relationship with Official Economy Nominal GDP. A unit increase in Demand Deposit will on the average result in 8999.52 unit decrease in Nominal GDP, while holding other explanatory variables constant. The parameter estimate of Ratio of currency in circulation to demand deposit is statistically significant as its absolute t-statistic value is greater thanthe absolute value of the 5\% critical value of t-statistic. Money Supply narrowly defined shows a positive relationship with Official Economy Nominal GDP. A unit change in money supply (M1) will on the average bring about 0.0006 unit change in Official Economy Nominal GDP, while holding other explanatory variables constant. The parameter estimate of money supply (M1) is statistically insignificant as its absolute t-statistic value is less thanthe absolute value of the $5 \%$ critical value of t-statistic.

The R-squared and Adj. R-squared are 93\% and 92\% respectively; this shows that the model has a high goodness of fit, as 93 percent of the total variation in the explained variable (Nominal Economy GDP) is explained by the regressed model. The F-statistics which measures the worthiness of the R-squared is statistically significant at 5\% significant level (critical value of F-statistic at 5\% significant level is 2.47), implying that the estimated model is fit for prediction and forecasting. Nevertheless, the estimated model is found to have positive autocorrelation problem $(\mathrm{DW}=1.33)$. 
Table 3. Regression Result: Dependent Variable (OFECON)

\begin{tabular}{lllll}
\hline Variable & Co-efficient & Standard Error & t-Statistic & Probability \\
\hline Constant & 9043.638 & 3332.374 & 2.713873 & 0.0119 \\
IFECON & 0.869615 & 0.432585 & 2.010274 & 0.0553 \\
IFEGDP & -173.0454 & 107.9135 & -1.603557 & 0.1214 \\
CIC & 14.98727 & 2.016567 & 7.432071 & 0.0000 \\
DD & 0.001705 & 0.001242 & 1.372827 & 0.1820 \\
CDD & -8999.522 & 3270.427 & -2.751788 & 0.0109 \\
M1 & 0.000609 & 0.000564 & 1.080387 & 0.2903 \\
$\mathbf{R}^{2}$ & 0.932698 & & & \\
Adj. $\mathbf{R}^{2}$ & 0.916546 & & & \\
F-statistic & 57.74379 & & & \\
Prob. (F-stat.) & 0.000000 & & & \\
Durbin-Watson & 1.325456 & & & \\
\hline
\end{tabular}

Source: Authors computation, 2015.

\section{Conclusion and Recommendations}

The impact of informal sector economy on economic growth in Nigeria is quite commendable. Even though, the relationship between informality and economic growth is not straight. Still, its contributions on growth are enormous as it serves as the bases of livelihood for rural dwellers in developing economies. We found endogenous growth model and monetary approach more relevant in our findings. However, informal economy has a significant and positive impact on official economy nominal GDP. It's evident that the currency in circulation to demand deposit, currency in circulation plus demand deposit, ratio of currency in circulation to demand deposit have positive impact on official economy nominal GDP.

The paper recommended thus, the need for the government to integrate the activities of the informal economy into formal sector and the size of the sector is measured and regulated because their roles are commendable. As it will improve tax collection and enhance fiscal policy.

The need for the government to provide enable environment for effective monitoring and supervision of the sector because most illegal activities operate in the informal sector where there is no or less regulation. This can influence the sector policy- wise if it knows what is happening in the informal sector which can be made possible through proper record keeping, documentation, accounting and regulation. 


\section{References}

Aryeetey, E., \& Hettige, M. (1997). Financial Market Integration and Reforms in Ghana, Malawi, Nigeria and Tanzania. World Bank Economic Review, 11(2), 195-218. https://doi.org/10.1093/wber/11.2.195

Awoyemi, O. (2012). Repositioning Nigeria informal sector: Shaping a new paradigm for sustainable Economic growth. Paper presented the CLAM business submit, lagos Nigeria. June.

Bagachawa, M. S. D. (1994). Financial integration and Development in Sub-Sahara Africa. A Study of informal finance in africa'MIMO.

Becky, K. F. (2004). Fact findings study, the informal Economy. Retrieved November 25, 2015, from http://www.rr.worldbank.orgldocumentlpapers linkslsida.pdf

Becky, K. F. (2004). The informal economy fact finding study. SIDA.

Chen, M. (2004). Rethinking the informal Economy: Linkages with the formal economy and the formal regulatory environment. Paper presented to unlocking the potential: Linking the informal and formal sectors. EGDI and UNU-WIDER conference, Helsinki.

Dickey, F. (1979). Testing for unit roots in autoregressive-moving average models of unknown order (pp. 599-609).

Ekpo, A. H., \& Umoh, O. J. (undated). The informal sector. Retrieved November 25, 2015, from http://www.onlinenigeria.comleconomics $\backslash$ ?blurb=945

Engel, R. F., \& Granger, C. W. J. (1979). Co-integration and error correction model: Representation, estimation, and testing: Econometrician, 55, 251-276. https://doi.org/10.2307/1913236

ILO. (2004). Globalization and the informal economy: How global trade and investment impact on the working poor. International labour organization, Geneva.

Masha, S. (2004). Monetary Policy and Macroeconomic Management in Informal Sector. Journal of Research and Contemporary issues, 2(2).

Nehemiah, E. O. (1995). An analysis of the effect of the growth of the informal sector on tax revenue performance in Kenya: AERC.

Nnanna, O. J. (2001). CBN/NIDB Survey on the status of SME(1) as SME(11) Beneficiaries(1997) bullion publication of $C B N, 25(3)$.

Robert, G. (1977). How credit money shapes the economy: The United States in a global system.

Yelwa, M., Obansa, S. A. J., \& Awe, E. O. (2015). Informality, Inclusiveness and Economic Growth in Nigeria. International journal of Management Science and Business Administration, 1(10). 